\title{
LAVAS ULTRABÁSICAS DA UNIDADE BASAL DO GREENSTONE BELT DE CRIXÁS (Go): UMA NOVA CLASSE DE ROCHAS ULTRABÁSICAS NO ESTADO DE GOIÁS
}

\author{
LINEU ALMEIDA DE SABOIA* e NOEVALDO ARAÚJO TEIXEIRA*
}

\begin{abstract}
The basal unit of the Crixás Greenstone belt is constituted of peridotitic and pyroxenitic flows intercalated with iron formation, chert, mafic and acid tuffs and intrusive bodies of piroxenite and babbro.

At the south end of the Crixás belt, the ultrabasic unite becomes thicker and the flows are best exposed, particulary along the Alagadinho Creek where detailed mapping was carried out.

Three types of ultrabasic flows were recognized: flows with spinifex texture (olivine) in the medium zone; flows with polyedral jointing and spinifex texture (clinopyroxene) in the upper zone; flows with polyhedral jointing.

The ultrabasic flows are composed of olivine, clinopyroxene, glass and opaques. The metamorphism of greenschist facies, together with deformation, have destroyed most of the primary volcanic textures and structures and changed partially olivine to serpentine and chlorite, clinopyroxene to tremolite-actinolite and glass to very fine chlorite.

A preliminary chemical work sugests that these ultrabasic rocks belong to the komatiitic suite, characterized by the ratio $\mathrm{CaO} / \mathrm{Al}_{2} \mathrm{O}_{3} \geq 1$ and low $\mathrm{TiO}_{2}, \mathrm{Na}_{2} \mathrm{O}$ and $\mathrm{K}_{2} \mathrm{O}$.

The identification in the greenstone belt of Crixás, of komatiitic peridotite, which represents a new type of ultrabasic rock in the Central Western Part of Brazil, implies a reevaluation of the "serpentine belt" and "alpine type" ultramafic rocks of that region.
\end{abstract}

INTRODUÇÃo Mais de uma centena de corpos ultrabásicos estão cartografados na porção central do Estado de Goiás. Estes possuem dimensões que variam entre $1 \mathrm{~km}$ até $100 \mathrm{~km}$ de comprimento, estando encaixados nós mais diversos tipos litológicos e níveis estratigráficos. Regionalmente foram interpretados como um cinturão serpentinítico do tipo Alpino, deśenvolvido de acordo com os clássicos conceitos de uma evolução geossinclinal (e.g. Almeida, 1968; Angeiras, 1968; Barbosa et al., 1969).

Este trabalho pretende redefinir alguns desses corpos "alpinos", colocando-os numa nova classe genética: corpos ultrabásicos extrusivos de filiação peridotítica Komatiítica. Esta redefinição baseia-se em três características:

1) Os corpos ultrabásicos fazem parte de uma sequiência greenstone belt e possuem idêntico posicionamento estratigráfico (base de cada ciclo de vulcanismo), quando comparados a outros corpos de sequiências vulcanogênicas arqueanas como as descritas no Canadá, Austrália, Rodésia e Áfríca do Sul (Anhaeusser et al., 1969; Anhaeusser, 1971, 1973; Glikson, 1976; Nesbitt, 1971; Viljoen e Viljoen, 1969; Baragar e McGlynn, 1976).

2) Identificação de estruturas como disjunção poliedral, texturas spinifex e mineralogia constituída por olivina em lâminas alongadas ou quench, esqueleto de clinopiroxênio e porções devitrificadas, semelhantes aos derrames ultrabasicos descritos por Pyke et al., (1973), Nesbitt (1971) e Viljoen e Viljoen (1969).
3) Quimismo idêntico aos komatítos, i.e., composição peridotítica com teores de $\mathrm{MgO}>20 \%$, alta razão $\mathrm{CaO} / \mathrm{Al}_{2} \mathrm{O}_{3}$ em torno de 1 , baixos teores em álcalis e $\mathrm{TiO}_{2}$ (Tab. 1).

As rochas ultrabásicas consideradas, desenvolveram-se como sucessivas unidades de lavas peridotíticas intercaladas com pelitos, formações ferríferas e cherts, constituindo a porção basal do greenstone belt de Crixás (Saboia, 1979).

Trabalhos anteriores Almeida (1968) em "Evolução Tectônica do Centro-Oeste Brasileiro no Proterozóico Superior" menciona a ocorrência de episódios tecto-orogênicos, caracterizados no início por processos evolutivos predominantemente de caráter eugeossinclinal, que assistiram a invasão de materiais infracrutais sob a forma de intrusões básicas e ultrabásicas, representantes do serpentine belt Goiano.

Angeiras (1968), ratificando o modelo proposto por Almeida (op . cit), sugere que os maciços serpentínitiços dispostos em forma linear, embora façam parte do Maciço Intermediário de Goiás, são intrusivos nos xistos Araxá, e se originaram do magmatısmo ofiolítico precoce.

Berbert (1970), estudando o cinturão serpentinítico de Goiás, definiu cinco grandes grupos de rochas, utilizando critérios petrográficos e geotectônicos, sendo os três primeiros de idade Pré-Cambriana:

1 - Dunitos - peridotitos serpentinizados do tipo Alpino;

* Metais de Goiás S/A - METAGO - Rua 68 n. 727 - Centro - 74.000 - Goiânia 
2 - Associação gabro-piroxenito - peridotito em grandes maciços;

3 - Associação piroxenito - gnaisses gábricos;

4 - Associação dunito-piroxenito-sienito alcalino;

5 - Diques de lamprófiros.

Para o autor acima citado, o cinturão sepentinítico de Goiás seria constituído pelo primeiro grupo (dunitos-peridotitos serpentinizados do tipo Alpino) e os grandes maciços como Niquelândia, Barro Alto e Cana Brava não fariam parte do cinturão.

Penna (1974), considera os maciços de Barro Alto, Niquelândia e Cana Brava como fatias do manto superior obductados sobre o Maciço Intermediário Goiano. Os corpos ultrabásicos seriam mais antigos que as faixas móveis laterais (e.g., Grupo Araxá).

Trabalhos mais recentes vieram acrescentar novos dados e suscitar dúvidas a respeito da colocação indiscriminada dos maciços ultrabásicos como complexos ofiolíticos, intrinsecamente relacionados à evolução geossinclinal do Grupo Araxá (Nilson et al., 1970; Figueiredo et al., 1975).

Atualmente, procura-se dissociar a evolução dos grandes maciços tipo Barro Alto, Niquelândia e Cana Brava, posicionados no embasamento siálico, dos pequenos plutons ultramáficos inseridos nos xistos do Grupo Araxá (e. g. Morro Feio, Cromínia, Pontalina, Mairipotaba e outros). Tais maciços, regionalmente, esboçam uma faixa alongada e estreita na região central do Estado que, 'segundo Schobbenhaus F. ${ }^{\circ}$, et al., (1975), dispõem-se segundo o "Lineamento Transbrasiliano"

Danni et al., (1973), caracterizando os diferentes tipos de rochas básicas-ultrabásicas na região Sudoeste da Serra Dourada, menciona a possibilidade de existência de derrames ultrabásicos representados por talco-clorita xisto.

Trabalhos de maior detalhe empreendidos por Stache (1976), Danni e Leonardos (1978), nos maciços de Barro Alto e Niquelândia respectivamente, mostram que os modelos propostos (estratiformes, alpinoestratiforme) não se adequam a uma série de dados por eles obtidos. Em Barro Alto, por exemplo, Stache (op. cit) mostra que os anortositos pertencem ao embasamento pré-Araxá, tendo sua ascenção dômica condicionada à intrusão do magma básico-ultrabásico. Da mesma forma, na região de Niquelândia, distintas sequiências litológicas, anteriormente englobadas como sendo componentes do maciço, foram desmembradas por Danni e Leonardos (op. cit). Foi reconhecida a existência de um conjunto granulítico - gnáissico de uma crosta muito antiga, na qual teria se posicionado tectonicamente a sequiência de anortosítos e anfibolítos da Serra dos Borges e a seqüência ultramámáfica da Serra da Mantiqueira.

$\mathrm{Na}$ caracterização das seqüências vulcano-sedimentares de Pilar de Goiás e Guarinos, Danni e Ribeiro (1978) evidenciam a existência de corpos ultra- básicos a elas relacionadas. A ausência de feições texturais e dados petroquímicos impediu, entretanto, que os referidos autores identificassem estes corpos como lavas ultrabásicas de filiação komatítica.

Saboia (1979) reconheceu derrames de rochas ultrabásicas no greenstone belt de Crixás, mostrandó inquestionáveis texturas spinifex, além de outras estruturas resultantes do resfriamento rápido de magmas de composição peridotítica e/ou piroxenítica.

Geologia regional $\mathrm{O}$ greenstone belt de Crixás (Saboia, 1979), configura-se como um alongado cinturão vulcano-sedimentar de direção norte-noroeste, constituindo-se em três faixas independentes: Faixa Crixás, Faixa Guarinos e Faixa Pilar. A Faixa Crixás, local deste estudo, é limitada a leste e sul pelo domo do Caiamar, a oeste pelo domo da Anta e a norte pelos metassedimentos do Grupo Araxá (Fig. 1).

A seqüência vulcano-sedimentar foi dividida em três grandes unidades litológicas. Unidade Basal, predominantemente constituída por rochas ultrabásicas extrusivas, intercaladas com pelitos e formações ferríferas, ocorrendo ainda pequenas intrusões, em forma de sills, de serpentinito, piroxenito e gabro. Unidade média, composta por lavas básicas com frequientes estruturas de lavas almofadadas, raros níveis de rochas ultrabásicas na base e pelitos intercalados. Unidade de topo constituída por rochas sedimentares de natureza pelítica grafitosa, raros níveis de estratos químicos, como formação ferrífera calcossilicatada e chert.

Em discordância estrutural sobre a seqüência vulcano-sedimentar, ocorre um pacote de clorita-muscovita-quartzo xisto e muscovita quartzito. Este mesmo pacote litológico foi definido na área de Pilar de Goiás por Danni e Ribeiro (1978), como pertencente ao Grupo Araxá.

Os domos siálicos, constituídos por gnaisses, são de natureza tonalítica e granodiorítica e formam ovóides no sentido empregado por McGregor (1951) e Anhaeusser et al., (1969): Tais domos arqueam os cinturões vulcano-sedimentares e localmente verticalizam suas camadas ao longo do contato.

Toda a seqüência apresenta paragênese do fácies xisto verde, tendo o metamorfismo atingido, localmente, o fácies anfibolito. $O$ conjunto ultrabásico acha-se representado por uma assembléia de xistos magnesianos com talco, clorita, tremolita e serpentina. As rochas básicas apresentam-se transformadas em anfibólio xistos com albita, epidoto, calcita e tremolita-actinolita. Os pelitos modificaram-se em vários tipos de micaxistos. As condições de metamorfismo de baixo grau que afetaram estas rochas não chegaram a destruir totalmente a sua mineralogia primária, nem mesmo das rochas ultrabásicas, onde ainda são observados relictos de olivina e clinopiroxênio.

A acentuada deformação tectônica com superposição de pelo menos três eventos, bem como as transformações mineralógicas advindas do metamorfismo, 


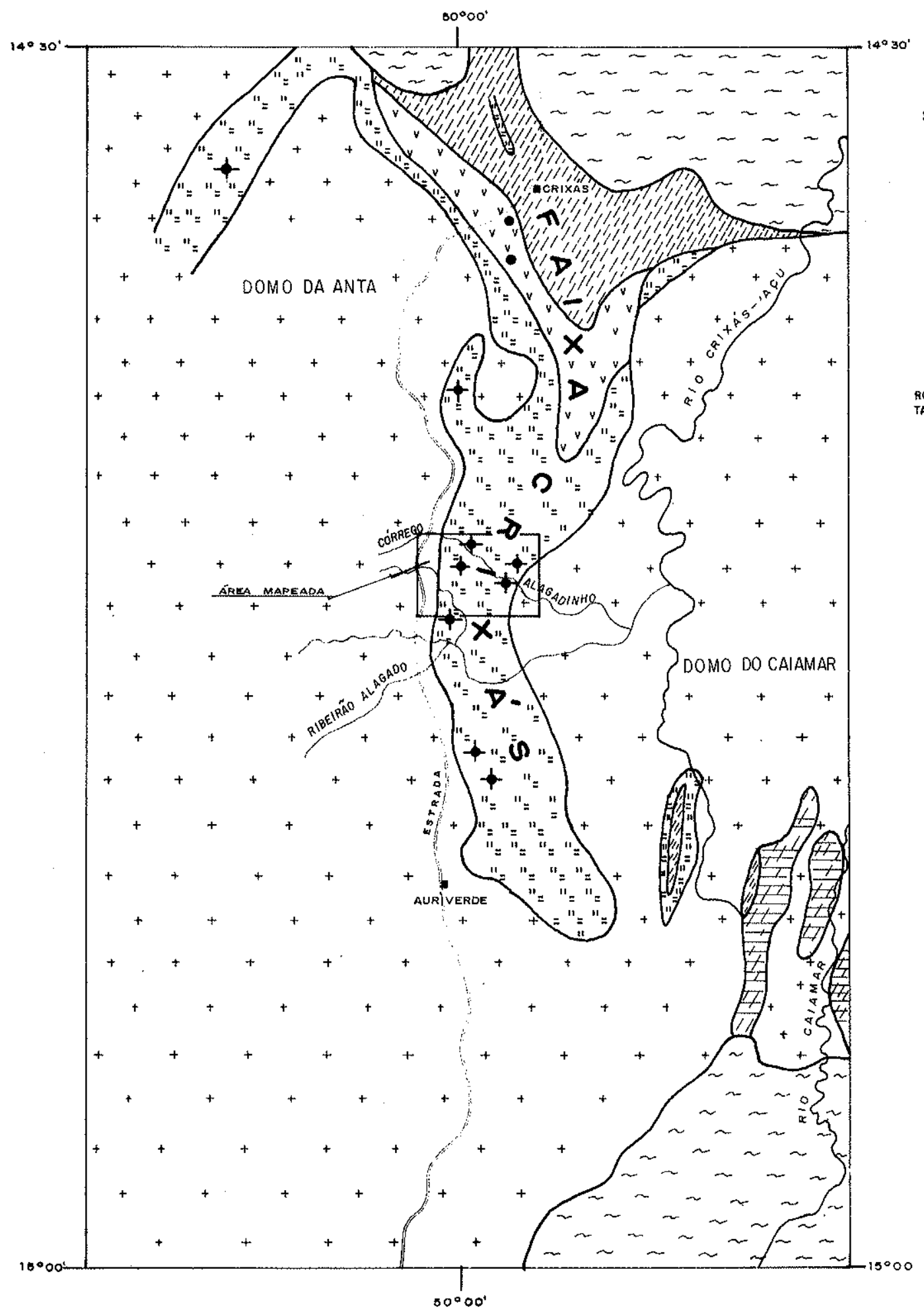

C ONVENGẼ ES

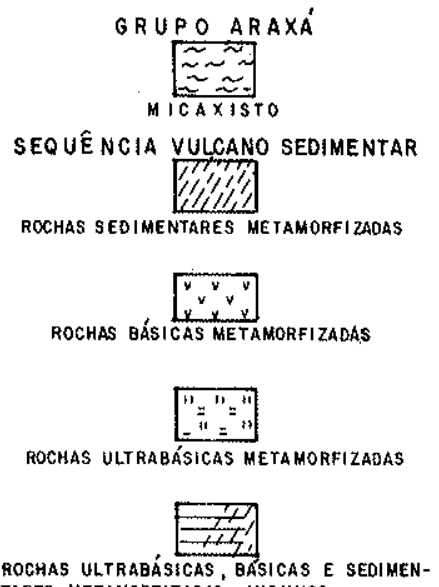

TARES METAMORFIZADAS - INDIVISO

\section{ROCHAS DO EMBASAMENTO

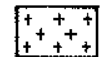

ROCHAS GRANITONGNAISSICAS

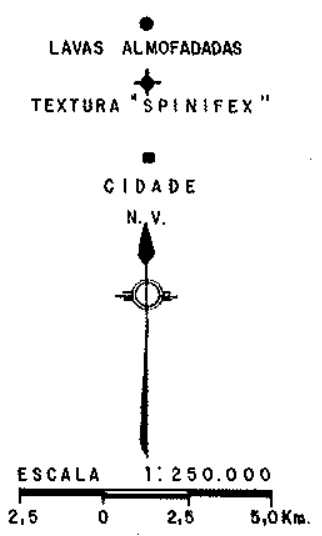

Modificodo de Gebrim (1.978)

Figura 1 - Mapa geológico do "Greenstone Belt" de Crixás - Faixa Crixás. Localização dos derrames ultrabásicos do Cór. rego Alagadinho. 
se encarregaram de destruir ou obscurecer grande parte das feições originais das rochas. Desta forma, embora acreditemos que grande parte da unidade basal do greenstone belt de Crixás seja constituída por derrames ultrabásicos, haja visto sua vasta distribuição ao longo da faixa, não temos certeza de sua proporção.

\section{Geologia local As regiões medianas e sul da} faixa Crixás (greenstone belt de Crixás) são constituídas por rochas ultrabásicas com intercalações de sedimento, que compõem a Unidade Basal daquela seqüência vulcano-sedimentar. Por apresentar algumas das melhores exposições dos derrames ultrabásicos, a região mediana cortada pelo Córrego do Alagadinho, foi mapeada na escala 1:20.000 (Fig. 2).

O mapa apresentado (Fig. 2) mostra a distribuição do pacote de lavas ultrabásicas, rochas intrusivas relacionadas e sedimentos. Este conjunto litológico acha-se limitado a oeste e leste pelos domos granitognáissicos da Anta e Caiamar, respectivamente. Os domos são blocos siálicos ovóides, constituídos predominantemente por ortognaisses leucocráticos, com fáceis localizados de anatexitos. Mineralogicamente são formados principalmente por feldspato calco-sódico, quartzo, biotita e muscovita.

De oeste para leste (Figs. 2 e 3), os seguintes tipos litológicos foram individualizados, na Unidade Basal da Faixa Crixás:

SERPENTINITO Os serpentinitos constituem aproximadamente $40 \%$ da área mapeada, estando em contato a oeste com os ortognaisses leucocráticos do domo da Anta e a leste com tremolita-clorita xisto. Apresentam-se maciços ou com foliação metamófica conspícua, mergulhando para sudoeste. Tais rochas não possuem qualquer estrutura primária conserva$\mathrm{da}$, constatando-se local e raramente a presença de pequenos nódulos de cromita e/ou magnetita. Veios de crisotita, são relativamente frequientes.

$\mathrm{Na}$ extremidade norte, a faixa serpentinítica acha-se intercalada com uma zona de derrames ultrabásicos com textura spinifex. Os derrames acham-se quebrados, estando representados por blocos isolados, o que dificulta a reconstituição das unidades vulcânicas. Em razão da existência de blocos de até $1,5 \mathrm{~m}$ de espessura apresentando spinifex grosseira, estima-se uma espessura de até 4 metros para os derrames ultrabásicos neste local.

As rochas originais, representadas pelo pacote de serpentinito, não podem ser definidas no momento, em razão da quase total inexistência de estruturas ou texturas primárias, podendo as mesmas representar lavas e/ou corpos intrusivos. As vezes identifica-se, localmente, restos de texturas spinifex intensamente deformadas, inseridas no serpentinito maciço.

XISTOS MAGNESIANOS Na zona centro-sul da área (Fig. 2), a unidade ultramáfica acha-se trans- formada em uma sequiência de xistos magnesianos. O contato oeste desta faixa com o serpentinito parece ser transicional. Os seguintes tipos litológicos são ïdentificados: talco tremolita xisto, talco-tremolita-clorita xisto, serpentina - talco xisto, talco-clorita xisto e talco xisto.

Na escala utilizada é impossível a separação das litologias acima referidas. Foi possível contudo individualizar faixas estreitas e descontínuas de derrames ultrabásicos com textura spinifex, que se dispõem de forma quase paralelamente na direção N10W. As primeiras ocorrências destas texturas são caracterizadas por intensa deformação que obscurece a torna dificil sua identificação. Localmente, observa-se a passagem gradacional de zonas com típica textura spinifex grosseira, para um xisto destituído de qualquer textura primária, possuindo apenas foliação metamórfica.

Um sill de metagabro com direção N10E, acha-se introduzido através de falhamento neste nível de xistos magnesianos. Apresenta-se cloritizado e intensamente foliado no seu bordo leste, transicionando a oeste para uma faixa anfibolítica até passar para uma zona mais maciça com predominância de anfibólio grosseiro e plagioclásio. A espessura do sill é de aproximadamente 30 metros.

DERRAMES ULTRABÁSICOS Os primeiros pacotes contínuos de derrames ultrabásicos peridotíticos são predominantemente maciços, estando em contato a oeste com os serpentinitos e os tremolita-clorita xisto e a leste com os derrames com textura spinifex. Os melhores afloramentos situam-se ao longo do Córrego do Alagadinho. Freqüentes veios com tęxtura spinifex com espessura entre $5 \mathrm{~cm}$ e $15 \mathrm{~cm}$ cortam indiscriminadamente porções destes derrames. Subordinadamente, ocorrem intercalações de estreitos derrames ultrabásicos com textura spinifex.

A seguir ocorre um nível onde predominam derrames ultrabásicos com texturas spinifex, fazendo contato a oeste com os derrames maciços e a leste com fino estrato sedimentar. Caracteriza-se por apresentar uma sucessão de derrames variando de 0,5 a $6 \mathrm{~m}$ de espessura. Ao longo da Serra da Lavrinha e Córrego do Alagadinho, estão as melhores exposições da faixa deste tipo de derrame. Ocorre aí uma excepcional intercalação de derrames peridotíticos, com espessura total estimada em aproximadamente $150 \mathrm{~m}$.

$\mathrm{Na}$ seção do Córrego do Alagadinho ocorre um corpo intrusivo de olivina prioxenito grosseiro com aproximadamente $25 \mathrm{~m}$ de espessura. Acha-se em contato a leste com um nível de quartzo-clorita xisto, que apresenta foliação bastante verticalizada, diferindo das medidas $\left(25-30^{\circ}\right)$ obtidas nas lavas. Tal fato sugere a ação da tectônica rígida ao longo do contato da seqüência com o domo do Caiamar ou talvez efeitos da própria ascenção deste. 


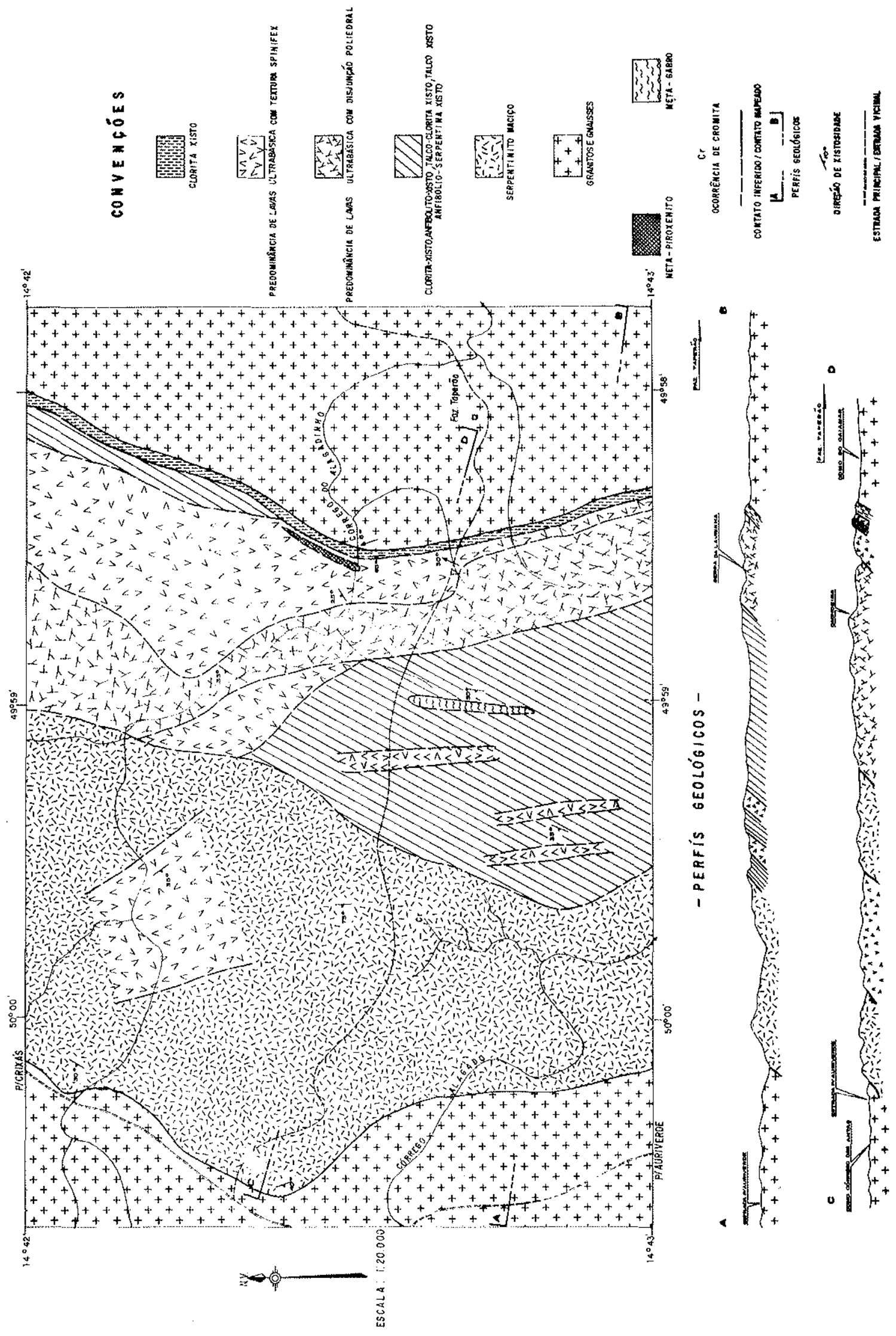

Figura 2 - Mapa geológico dos derrames ultrabásicos do Córrego Alagadinho. Geologia por Saboia, Teixeira e Salles. 
Focies de clorito tolco

xisto antibolio xisto,
clorito-serpentina xisto
comestruturo vulcônica.

Lavas uitrabósicos com

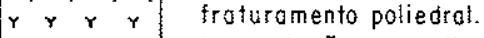

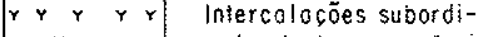

r $r$ r nodos de lovas com spinifex.

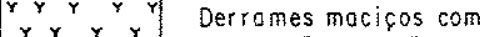

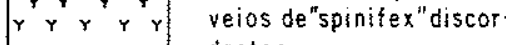

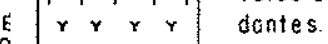

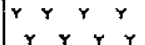

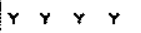

A coluna apresentado, tem que ser concebido como tentativa em razão do desconhecimento global àas feicões tectônicas do belt. Desto for ma os estudos mais específicos poderõo mudar a concepcão litoestratigráfico atual. Se confirmar a possibilidade do pacote estar isoclinalmente dobrado a espessura representada deste torno-se bem mais reduzido.

Serpentinito foli ado ou macico

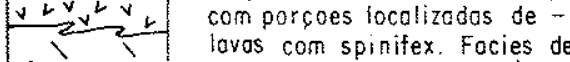

$1 / 1$ tolco-ciorita xisto e anfibólio-

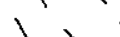

$-1-1$

Domo gnáissico ovóide

1 $+_{++}^{+}++_{+}^{+}++^{+}++$

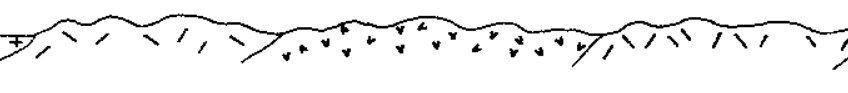

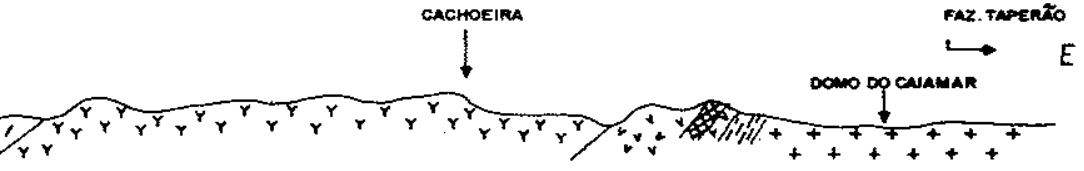

Iste perfil constifui a secão tipo do pacote ultrabásico mopeado De oeste paro leste identifica-se serpentinito foleado localmente com clorita. Nãa possui estrutura vulcônico visível. Transiciono para foixas com lavas o "spinifext" 0 confato destos duas faixos não é muito claro. O primeiro nivel continuo de lavas ultrabásicos säo carocterizados par frafuromento poliedral e niveis discordantes de "spinifex", na cochoeira situom-se os melhores afloramentos. Pequenos trechos de derrames com zonas de "spinitex" grosseiro (lâminas de ofe $1 \mathrm{~mm}$ ), corpos de piroxenitos intrusivo e nivel sedimentar associodo finalizam a secöo vulcono sedimentor do perfil. 
Derrame ultrabásico com textura spinifex (olivina) na zona média. Espessura entre 0,5 até $30 \mathrm{~m}$. (Foto 5) Afloramentos no Córrego Alagadinho, e entrada para Fazenda Taperão.

Derrame ultrabásico com disjunção poliedral e zona superior com textura spinifex (clinopiroxênio). Afloramentos na Cachoeira e Serra da Lavrinha.

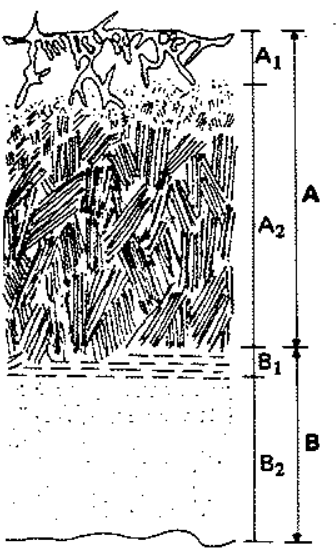

Topo do derrame fraturamento poliedral

Textura spinifex: as lâminas tornam-se mais alongadas em direção a base do.derrame.

Olivina esqueletal foliada.

Peridotito maciço de granulação fina a média.

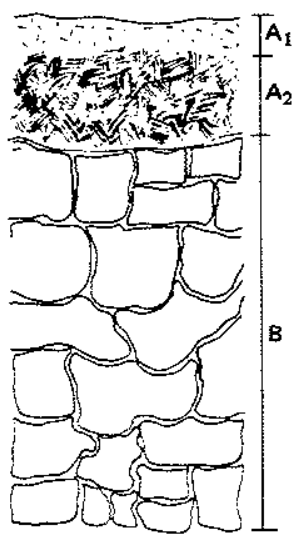

Topo afanítico gradando para zona com textura spinifex. Há uma sensível predominância de clinopiroxênio sobre a olivina.

Peridotito maciço, com disjunção poliedral.

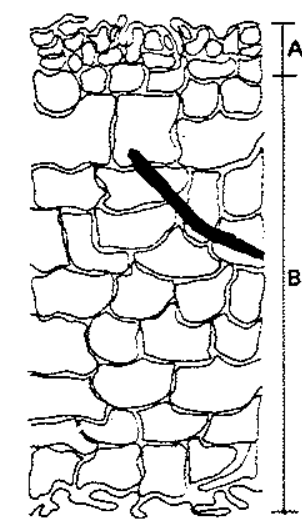

Topo com fraturamento poliedral fino.

Peridotito maciço de granulação fina a média com espesso fraturamento poliedral.

Localmente veios com textura spinifex.
As dimensões de cada subunidade dos derrames guardam geralmente uma proporção constante. $\mathrm{O}$ contato com a subunidade $\mathrm{A}_{2}$ é inteiramente transicional, marcado pelo aparecimento de lâminas $\mathrm{e}$ pseudomorfos de olivina dispostos alternadamente com clinopiroxênio esqueletiforme. A textura torna-se mais grosseira em direção à base do derrame.

Subunidade $B_{1}$, pode ou não estar presente, normalmente faz um ângulo de aproximadamente $90^{\circ}$ com a faixa de spinifex. Feições abauladas reentrantes da subunidade $A_{2}$ na faixa do peridotito foliado também pode ser observado.

A unidade $B$, macroscopicamente fornece pouca informação. Apresenta-se afanítica, maciça, raramente apresentando cristais de olivina esqueletiformes.

Os derrames maciços apresentam como principal característica o fraturamento poliedral e os veios de spinifex. $\mathrm{O}$ fraturamento no topo é bem mais compacto que na base.
$A_{1}$ - Massa predominantemente constituída por serpentina e clorita com cristais esqueletiformes de olivina imersos. Há uma predominância de matriz em relação aos fenocristais.

$\mathbf{A}_{2}$ - Porção superior: spinifex fina, lâminas de olivina serpentinizada orientadas ao acaso ou em padrões triangulares. Grande quantidade, de vidro, metamorfisado em clorita serpentina.

- Porção média : textura spinifex grosseira, em alguns afloramentos. A lâminas de olivina chegam a alcan çar $60 \mathrm{~cm}$. Normalmente os cristais intersticiais de clinopiroxênio possuem dimensões bem mais reduzidas.

$\mathrm{B}_{2}-$ Apresentam cristais serpentinizados de olivina em matriz de anfibólio da série tremolita-actinolita que substituem os antigos cristais de clinopiroxênio. Nesta unidade (B), é sintomática a ausência das lâminas tanto de olivina como clinopiroxênio. Texturalmente apresenta feições de cumulato. tado por veios possuindo texPoto 13). Ser

da Lavrinha e Cachoeira.

Figura 4 - Esquema dos tipos de derrames ultrabásicos no Greenstone Belt de Crixás 
Descriçăo dos diferentes tipos de derrames ultrabásicos $\mathrm{Na}$ porção leste da área (Fig. 2) observou-se a existência de uma faixa contínua de rochas ultrabásicas de direção N10W na qual ocorrem três tipos de derrames (Fig. 4):

1) Derrame ultrabásico com textura spinifex (olivina) na porção média;

2) Derrame ultrabásico com disjunção poliedral e zona superior com textura spinifex (clinopiroxênio);

3) Derrame ultrabásico maciço com disjunção poliedral.

Dos três tipos de derrames ilustrados na Fig. 4, dois se identificam perfeitamente com os derrames ultrabásicos descritos no cinturão Abitibi, no Canadá, por Arndt et al., (1977, pp. 338), Pyke et al., (1973). Os derrames com espessa zona basal com disjunção poliedral e fina zona com textura spinifex com predominância de clinopiroxênio (tipo 2), corresponderia a um novo tipo de estrutura de lava ultrabásica arqueana.

As diferenças texturais e estruturais entre os três tipos de derrames identificados têm sido consideradas como resultantes de dois principais mecanismos:

a) - diferentes intensidades na separação por gravidade, precipitando os fenocristais de olivina, a partir do líquido ultrabásico; b) distintas relações entre líquido e fenocristais de olivina no magma ultrabásico. Como consequiência, os derrames com texturas spinifex evidenciam uma maior separação líquido-sólido e uma alta razão líquido/fenocristais. Por outro lado, os derrames maciços com disjunção poliedral representam $o$ inverso.

\section{1 - DERRAME ULTRABÁSICO COM TEXTURA} SPINIFEX (OLIVINA) NA PORÇÃO MÉDIA Este tipo de derrame foi estudado por Pyke et al., (1973), na área de Munro Township, no Canadá, e aqui adotaremos a terminologia usada pelos referidos autores.

Os derrames com zona média, constituída por textura spinifex, foram divididos numa unidade superior A e uma inferior B, cada uma podendo ser subdividida. A porção superior é caracterizada por uma zona de resfriamento rápido, apresentando fraturamento e textura afanítica (subunidade A1), que passa para uma zona de textura spinifex grosseira (subunidade A2).

$A$ unidade $B$ foi dividida em quatro subunidades: subunidade B1, caracterizada por uma faixa com textura spinifex, com placas de olivina orientadas paralelas aos planos dos derrames; subunidade B2 (semelhante a subunidade B4), constituida por peridotito maciço com textura cumulus; subunidade B3, designada por Pyke (op. cit.) como peridotito nodular, é formada por uma zona maciça, localmente constituída por uma estreita faixa nodular de clinopiroxênios.

Unidade Superior A : Subunidade Al Sua principal característica são os fraturamentos poliedrais das porções de topo dos derrames, estes mais regulares nas porções extremas do topo. Em direção à zona com spinifex (A2), não se individualizaram mais as figuras poliédricas, mas sim fraturas reentrantes, sempre preenchidas por clorita e carbonato. $O$ contato com a subunidade A2 é transicional, sendo marcado pelo aparecimento de finas lâminas pseudomorfizadas de olivina dispostas triangularmente, ou com distribuição aleatória (Foto 1).

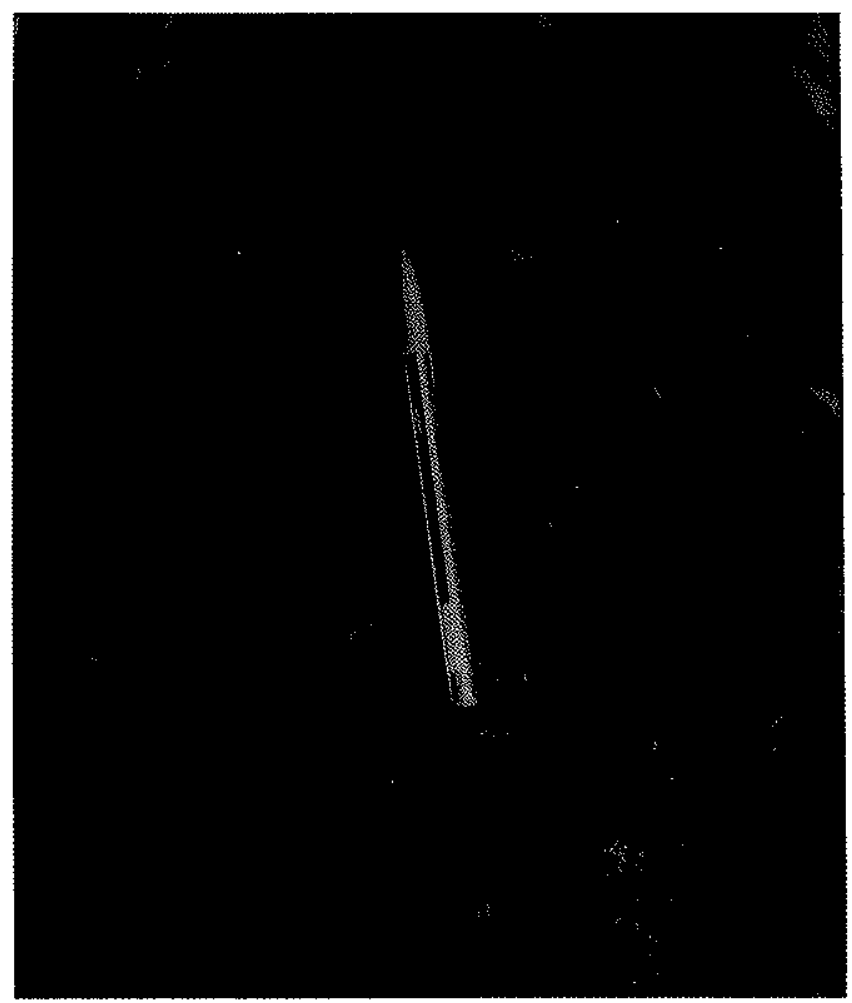

Foto 1 - Derrame com textura spinifex. Notar a gradação da textura spinifex grosseira até fina. Zona de topo macico com fraturamento.

Subunidade A2 A textura spinifex nos derrames mapeados apresenta grande variedade de formas e dimensões, sendo entretanto característicos os arranjos triangulares (Foto 2) e as ripas regularmente espaçadas (Foto 3). Os cristais maiores são sempre pseudomorfos de olivina, que se apresentam como alongadas lâminas, às vezes alcançando dimensões extraordinárias de até quase $1 \mathrm{~m}$, como as encontradas em afloramentos no Córrego do Alagadinho. A maior espessura constatada para esta subunidade situa-se em torno de $3 \mathrm{~m}$.

Microscopicamente, as feições do topo da Subunidade A2 são representadas por texturas spinifex fina, com desenvolvimento de lâminas de olivina serpenti- 


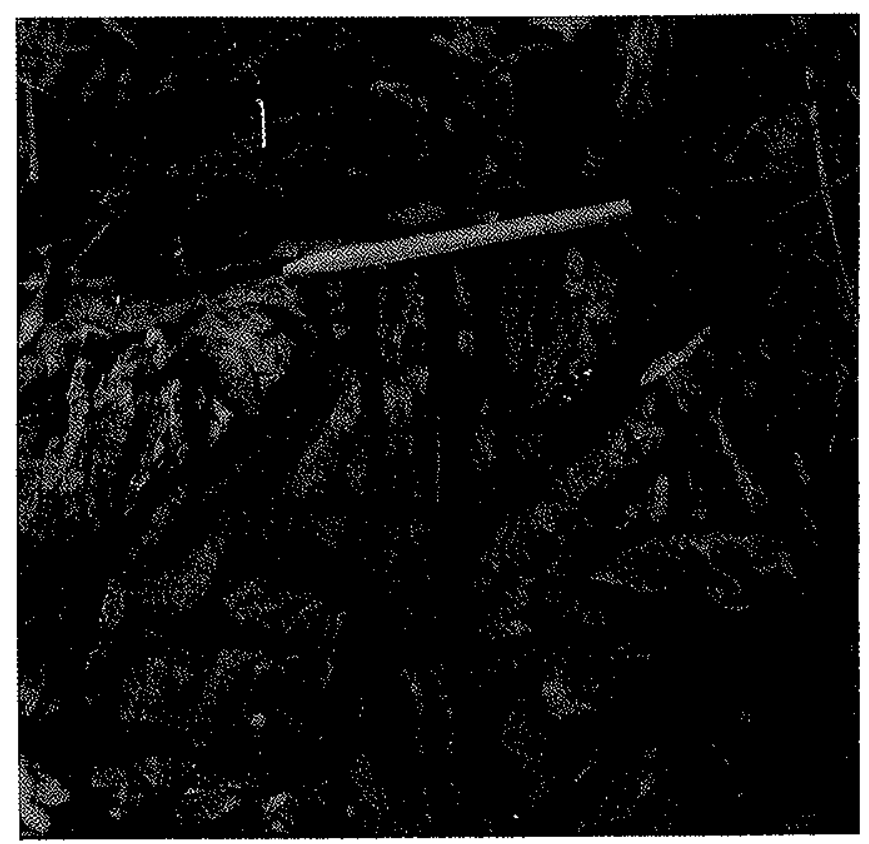

Foto 2 - Detalhe da zona média dos derrames com textura spinifex grosseira. As ranhuras mais pronunciadas representam as lâminas de olivina. Textura spinifex em pảdão triangular.

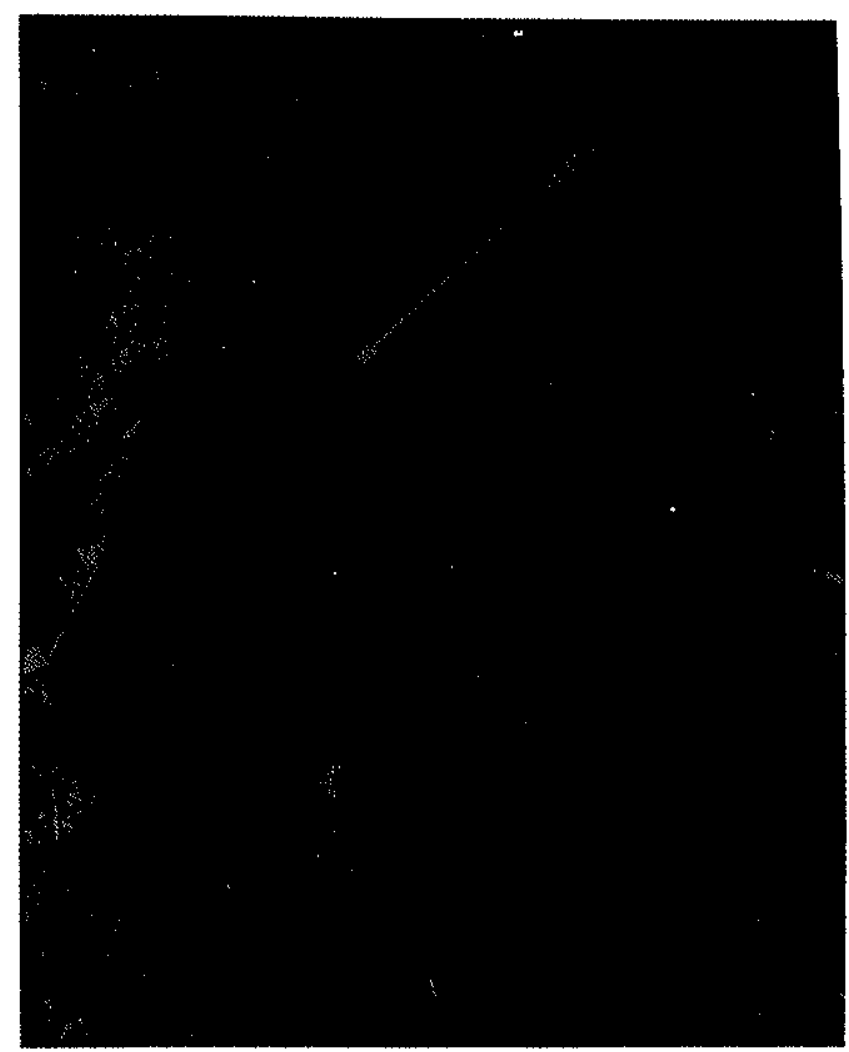

Foto 3 - Derrame com zona de textura spinifex grosseira transicionando para porção superior, caracterizada por lâminas menores de olivina em padrões triangulares. Notar o contato brusco, incomum, entre as duas subunidades. nizadas, orientadas ao acaso, sendo interceptadas por pseudomorfos de clinopiroxênio (Foto 4). O padrão triangular mostra alternância de lâminas de olivina serpentinizadas e ripas finíssimas de clinopiroxênio anfibolitizado. No centro das figuras triangulares, às vezes, observa-se, em lugar de clinopiroxênio, feições de desvitrificação (Foto 5).

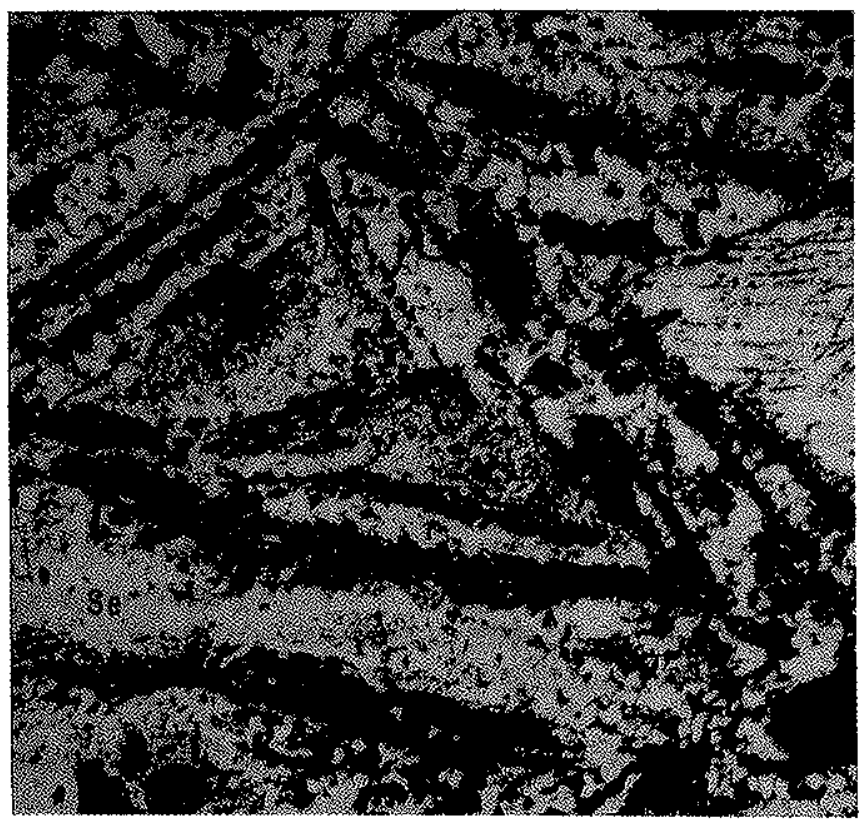

Foto 4 - Detalhe microscópico da zona de topo. Lâminas de olivina (01) dispostas em padrão triangular. No centro, finos cristais de clinopiroxênio. Porções escuras representam serpentina e clorita. Nicois $\mathrm{X}, 25 \mathrm{x}$.

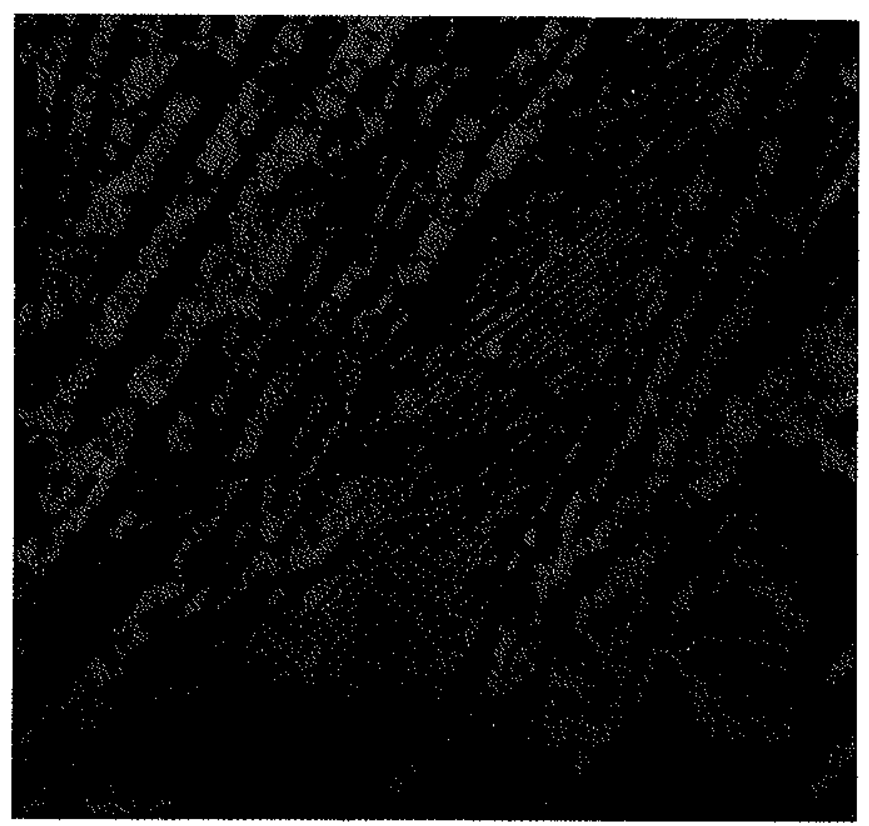

Foto 5 - Lâminas de olivina serpentinizadas (Se) dispostas em padrão triangular. No canto direito concentração de clinopiroxênio em forma de ripas muito finas. No centro dos triângulos feições de desvitrificação. Nicois $\mathrm{X}, 25 \mathrm{x}$. 
Os espaços entre as lâminas paralelas de olivina são invariavelmente ocupados por estreitos e também alongados cristais esqueletais de clinopiroxênio, que sempre fazem um pequeno ângulo no contato com as lâminas de olivina. Âs vezes também apresentando-se em crescimentos radiais. As amostras mais intensamente metamorfisadas apresentam a olivina sempre transformada em serpentina e clorita e o piroxênio em tremolita. Deve-se ressaltar que mesmo quando não é é mais possível constatar a mineralogia primária, a textura spinifex é facilmente identificável (Fotos 2 e 3).

As rochas das porções médias das unidades A2 apresentam textura spinifex grosseira e mostram, geralmente, paragênese constituída por clorita (clinocloro), serpentinita, anfibólio da série tremolita-actinolita e óxidos. Os grandes cristais pseudomorfisados de olivina apresentam disposição paralela ou triangular, formando ângulos bem agudos com as faixas constituídas de diminutos cristais esqueletiformes de clinopiroxênio (Foto 6). Nos centros destes cristais ocorrem exsoluções de magnetita (Foto 7). A disposição dos esqueletos, tanto podem desenvolver-se paralelamente, com arranjo radial, ou de forma triangular (Foto 8).

Os efeitos tectônicos são os que mais obscurecem as texturas originais. Principalmente ao longo da faixa serpentinítica a oeste, verifica-se zonas com texturas spinifex grosseira, que gradativamente se transformam em uma rocha totalmente homogênea maciça ou foliada, sem qualquer vestígio das texturas primárias.

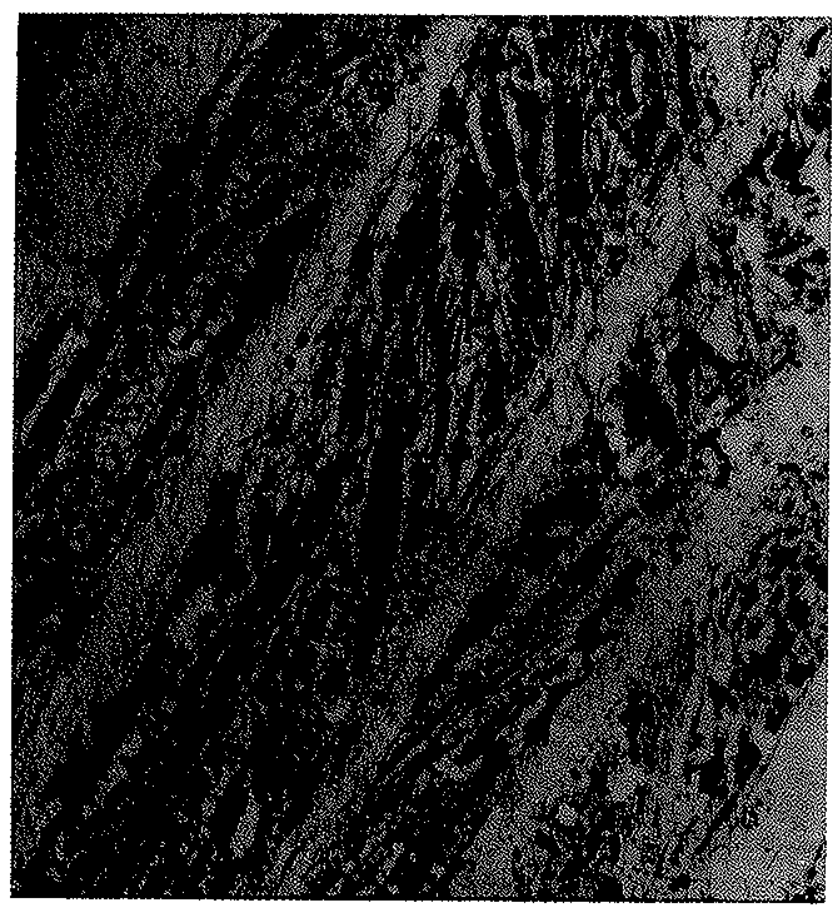

Foto 6 - Detalhe microscópico da subunidade $\mathrm{A}_{2}$, com lâminas de olivina serpentinizadas (Se) dispostas paralelamente, alternando-se com faixas constituídas de clinopiroxênio esqueletal. Nicois $/ /, 34 \mathrm{x}$.
Na subunidade A2, a textura spinifex apresenta um sentido de polaridade estratigráfica facilmente aplicável, constituindo-se em uma importante ferramenta para a determinação da seqüência estratigráfica. A textura spinifex invariavelmente se afina em direção ao topo dos derrames, até tornar-se imperceptível na zona de fraturamento do topo (A1). Além disto, parece ser regra geral, o sentido de crescimento das lâminas de olivina desta zona sempre perpendiculares aos planos de extrusão das lavas ultrabásicas (Fotos '1 e 3).

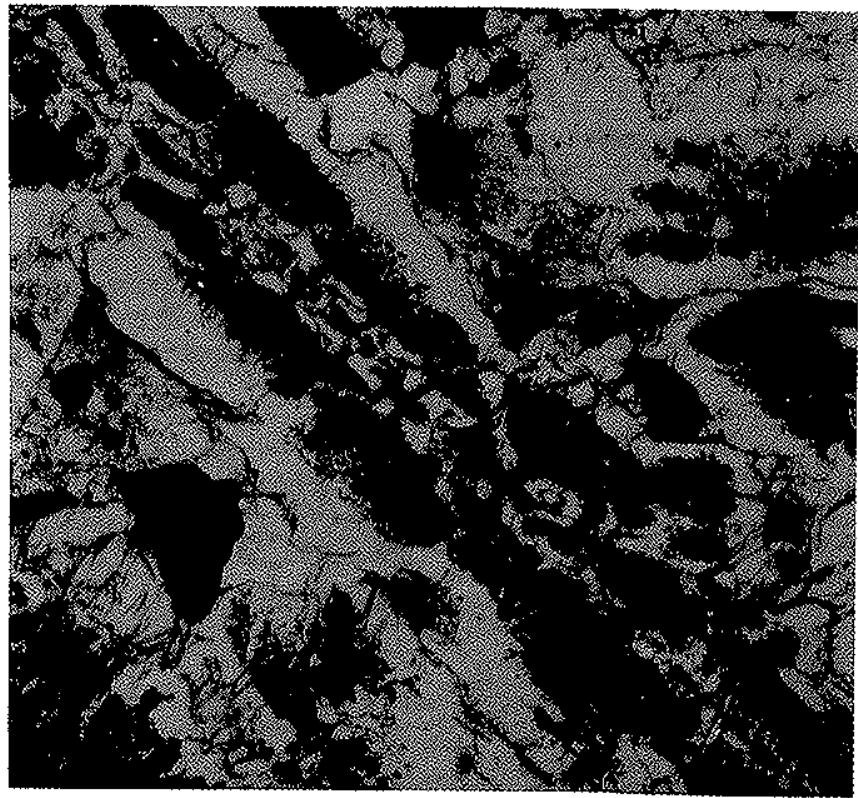

Foto 7 - Detalhe da foto 6 , cristal esqueletal de clinopiroxênio no centro. Notar o aspecto de vértebras e exsoluções de magnetita. Nicois //,25x.

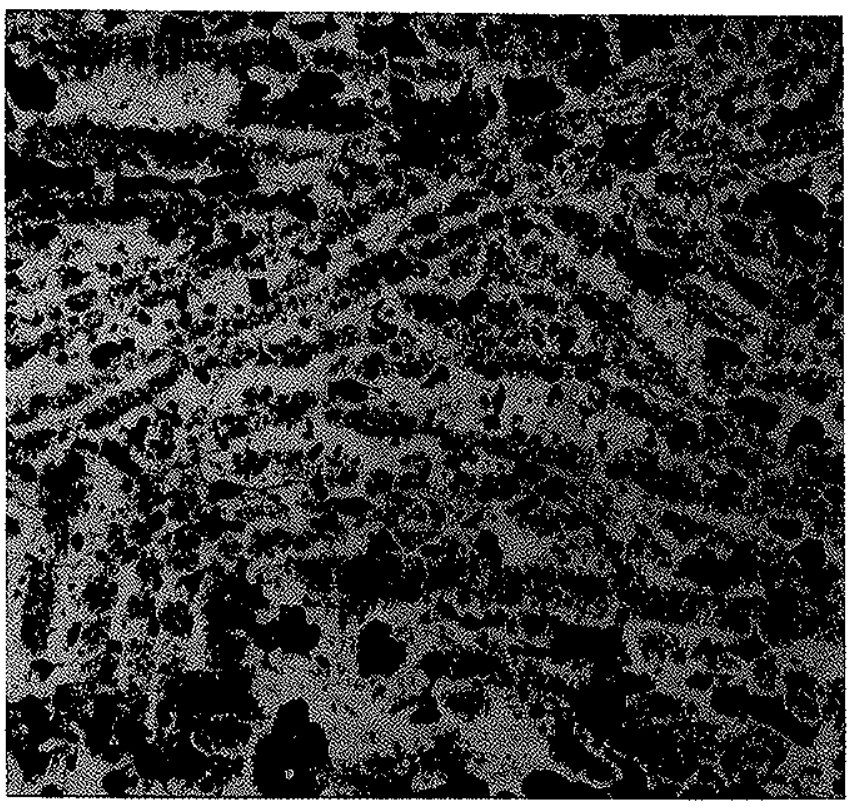

Foto 8 - Textura spinifex em padrão triangular, com os pseudomorfos de clinopiroxênio marcados pelas exsoluções de opacos. Nicois //, 25x. 
Pyke et al., (1973), dividem as porções maciças dos derrames em quatro subunidades B1, B2, B4 e B3. A primeira B1, corresponde ao peridotito foliado, B2 e B4 ao peridotito granular fino a médio e a B3 ao peridotito nodular. Nos derrames peridotíticos de Crixás, muito raramente constata-se a presença de peridotito nodular, talvez pelo acentuado estágio de serpentinização dessas rochas destruindo praticamente esta estrutura primária. Desta forma, a subunidade B2 constitui, quase que integralmente, as porções basais dos derrames. São rochas inteiramente homogêneas, maciças, de granulação fina a média (Foto 9). Assim, a base do derrame pode ser dividida em apenas duas subunidades B1 e B2.

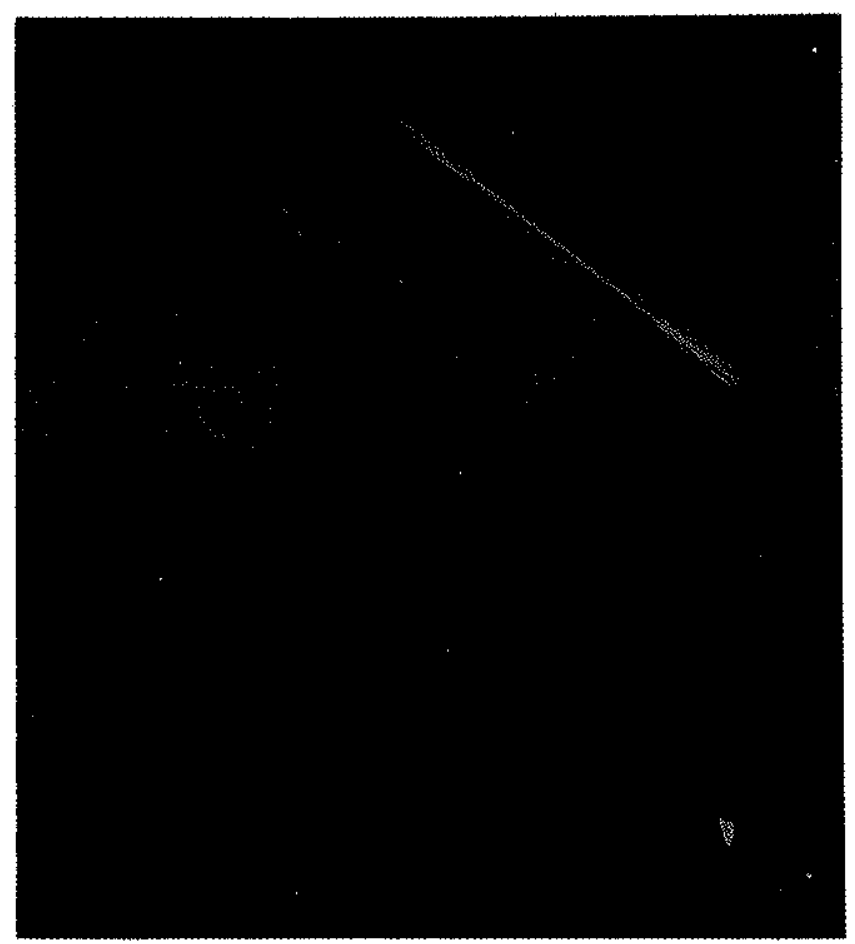

Foto 9 - Detalhe do derrame ultrabásico mostrando a subunidade $\mathrm{A}_{2}$ com textura spinifex grosseira, zona estreita de spinifex foliada $\left(B_{1}\right)$ e base $\left(B_{2}\right)$, maciça afanítica.

Unidade Inferior $B \quad$ Subunidade B1 A primeira apresenta espessura variável, geralmente em torno de $20 \mathrm{~cm}$, sendo caracterizada por arranjo paralelo das lâminas alongadas de olivina (Foto 2 e Foto 9). $O$ contato com a zona sobrejacente (subunidade A2) é brusco e com a subunidade B2 é transicional, marcando o início das porções maciças dos derrames. Foram identificados dois tipos de contatos entre esta zona (B1) e as porções com textura spinifex (A2): a) contatos em ângulos de aproximadamente $90^{\circ}$ entre as lâminas de textura spinifex grosseira e as porções com textura spinifex foleada; b) contatos ondulados ou abaulados entre as duas subunidades. Este último tipo é mais raro que o primeiro.
Subunidade B2 Tomando-se por base a mineralogia metamórfica, infere-se que esta porção do derrame é constituída quase que exclusivamente por olivina, com pouco material piroxenítico intersticial. Em alguns derrames na Serra da Lavrinha identificou-se, nas zonas basais, a presença de olivina quench (Fotos 10 e 11), semelhantes às descritas por Nesbitt (1973) e Viljoen e Viljoen (1969).

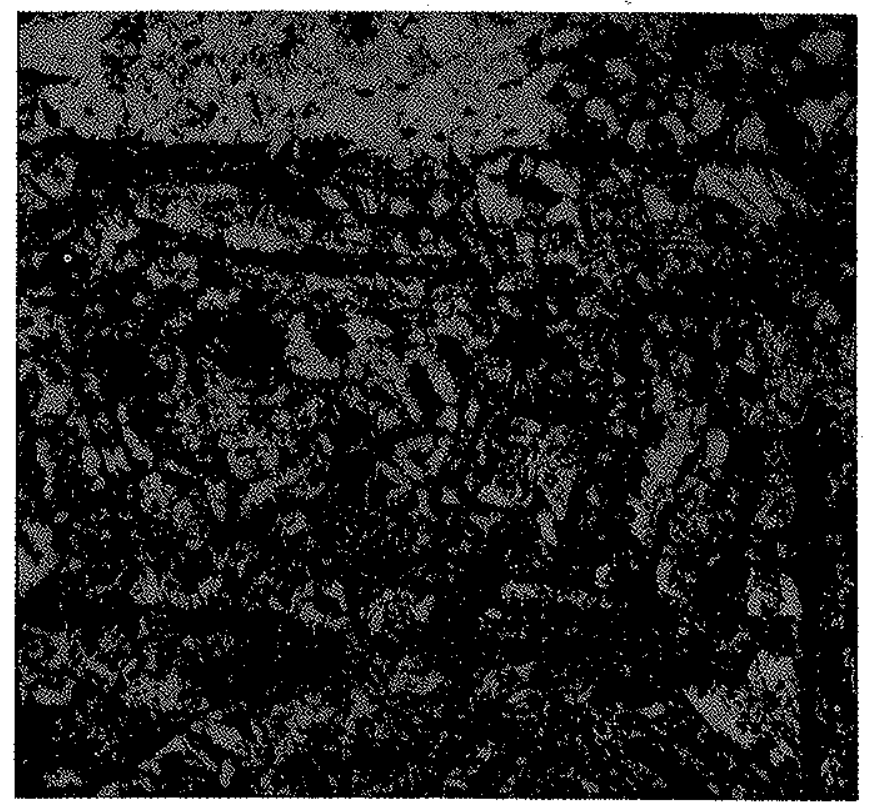

Foto 10 - Detalhe do cristal de olivina quench das porçoes basais dos derrames ultrabásicos. $\mathrm{O}$ cristal acha-se praticamente transformado em serpentina. $\mathrm{Na}$ porção superior agregado de tremolita. Nicois $X, 25 x$.

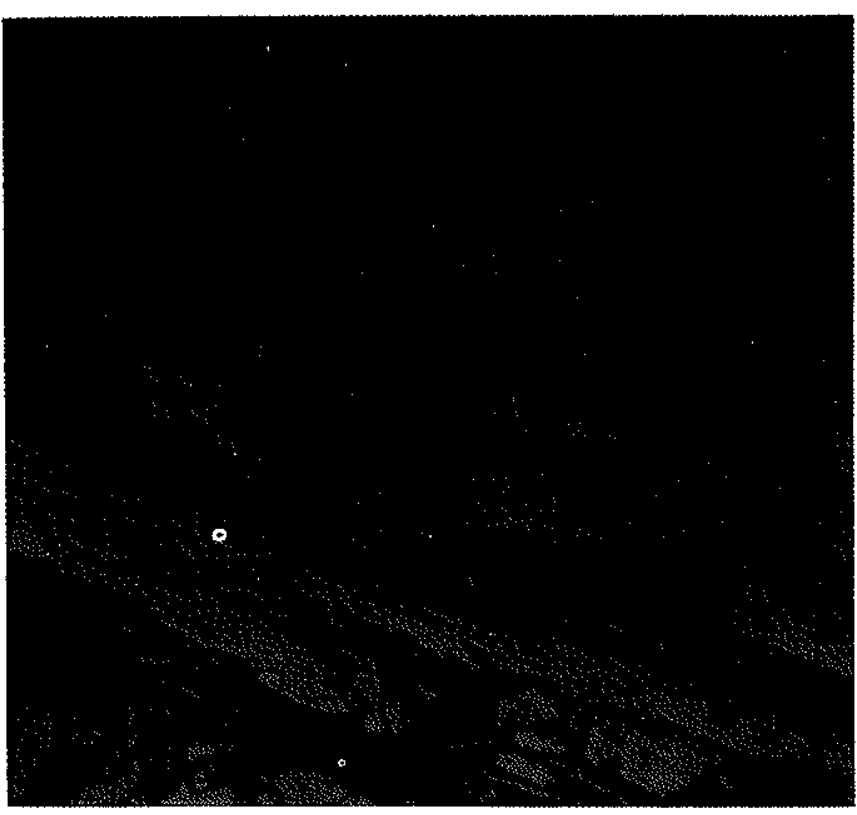

Foto 11 - Zona de base de derrame ultrabásico $\left(B_{1}\right)$. Notar os cristais quench de olivina (01); no centro da foto ripas alongadas de olivina com exsolução de magnetita nos bordos. Nicois $/ /, 25 x$. 
É importante notar que a estrutura de um derrame como um todo também apresenta um sentido de polaridade estratigráfica, dada por um topo fraturado e uma base maciça, podendo ser muito útil no mapeamento de seqüência vulcano-sedimentares arqueanas. $\mathrm{Na}$ área mapeada foram constatadas, localmente, inversões estruturais dos derrames ultrabásicos com textura spinifex.

\section{2 - DERRAME ULTRABÁSICO COM DISJUN-} ÇÃO POLIEDRAL E ESTREITA ZONA COM TEXTURA SPINIFEX (clinopiroxênio) Este tipo de derrame não se encontra ainda descrito na literatura sobre lavas ultrabásicas arqueanas. É constituído por duas unidades, A e B, sendo a primeira subdividida em A1, zona de resfriamento de topo, e A2, porção com textura spinifex formada predominantemente por clinopiroxênio. A segunda (B) é formada por uma zona basal maciça espessa, apresentando disjunção poliedral.

Unidade Superior $A$ Subunidade Al Corresponde à zona de topo do derrame. Neste tipo de derrame esta zona é fina $(5 \mathrm{~cm})$, sendo constituída por uma rocha homogênea maciça que grada para uma zona de textura spinifex fina e daí para uma spinifex grosseira. $Q$ fraturamento poliedral desta zona, comum nos outros tipos de derrame, não foi aqui observado.

Subunidade A2 É constituída por uma zona de textura spinifex grosseira, que se torna gradativamente mais fina para a zona de topo (A1), até tornar-se imperceptível. Faz contato brusco com a zona basal maciça com disjunção poliedral (unidade inferior B). A textura spinifex é formada por esparsas placas de olivina, com os espaços entre as mesmas preenchidos por clinopiroxênio. Em alguns locais, os cristais (placas) de olivina chegam até mesmo a desaparecer, ficando a rocha constituída por clinopiroxênio em mas$\mathrm{sa}$, que parece ter sido vidro originalmente. Neste caso, as texturas desta zona não são tão grosseiras e o clinopiroxênio assume as formas mais diferentes possíveis (escamas, signoidal), estando orientado aleatoriamente.

Esta subunidade é bastante descontínua nos vários derrames. Em alguns pontos, a textura spinifex fina e grosseira se interdigitam, sugerindo vários fluxos de líquido ultrabásico.

Unidade Inferior $B \quad$ Esta zona é a mais espessa do derrame, constituindo geralmente $3 / 4$ do mesmo e é formada por uma rocha homogênea, maciça, com disjunção poliedral. Não foi observada polaridade no tamanho dos poliedros em relação à base e topo do derrame. $\mathrm{O}$ contato com a subunidade $\mathrm{A} 2$ é brusco, assim como com a subunidade Al do derrame inferior. A rocha é constituída predominantemente por olivina com pouco clinopiroxênio intersticial.
$\mathrm{Na}$ base de alguns derrames foram observadas algumas estruturas circulares $(2 \mathrm{~cm})$, que podem corresponder à zona de peridotito nodular. Esta zona nodular nestes derrames é fina $(5 \mathrm{~cm})$, sendo que os nódulos ainda não foram estudados em detalhe; talvez correspondam a aglomerados de clinopiroxênios.

3 - DERRAME MACIÇO COM FRATURAMEN. TO POLIEDRAL Este tipo de derrame ultrabásico acha-se discutido e esquematizado em Arndt $e t$ al., (1976, p. 338) e Arndt (1976). Na região de Crixás ocorrem excelentes exposições destes derrames maciços com fraturamento poliedral. Principalmente ao longo da estrada para a Fazenda Taperão. Em geral tais derramès possuem espessuras superiores aos derrames com textura spinifex e localmente apresentam-se cortados por veios ou zonas irregulares com textura spinifex. Tais feições representam injeções de líquido ultrabásicos posteriores ao resfriamento dessas lavas (Fotos 12 e 13). Este tipo de derrame foi dividido em duas subunidades: superior $\mathbf{A}$ e inferior $\mathbf{B}$.

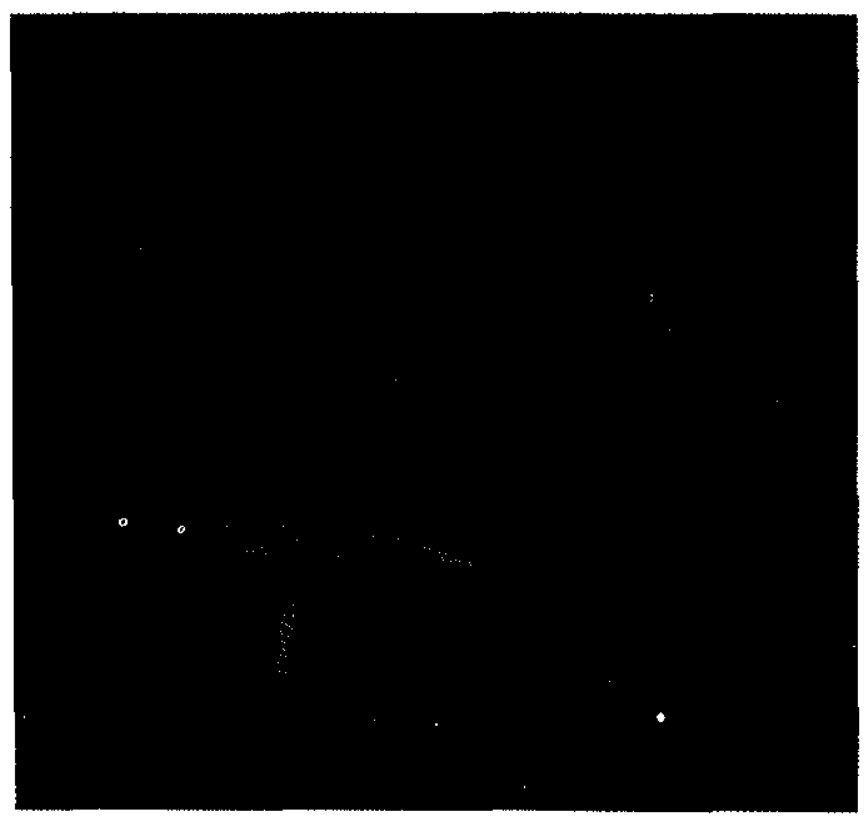

Foto 12 - Derrame ultrabásico maciço com veios apresentando textura spinifex. No alto, fraturamento poliedral.

Unidade Superior $A \quad$ É constituída por uma zona de topo com fraturamento poliedral fino. As figuras retangulares ou poliedrais apresentam dimensões inferiores quando comparadas com as porções médias e basais, permitindo o estabelecimento no sentido base-topo (Fig. 4).

Unidade Inferior $B \quad \hat{E}$ formada por rochas de coloração cinza-esverdeada, normalmente homogêneas, e de granulação fina, observando-se às vezes pequenos veios de serpentina. Os poliedros são bem mais amplos e o fraturamento bem mais espaçados que a 


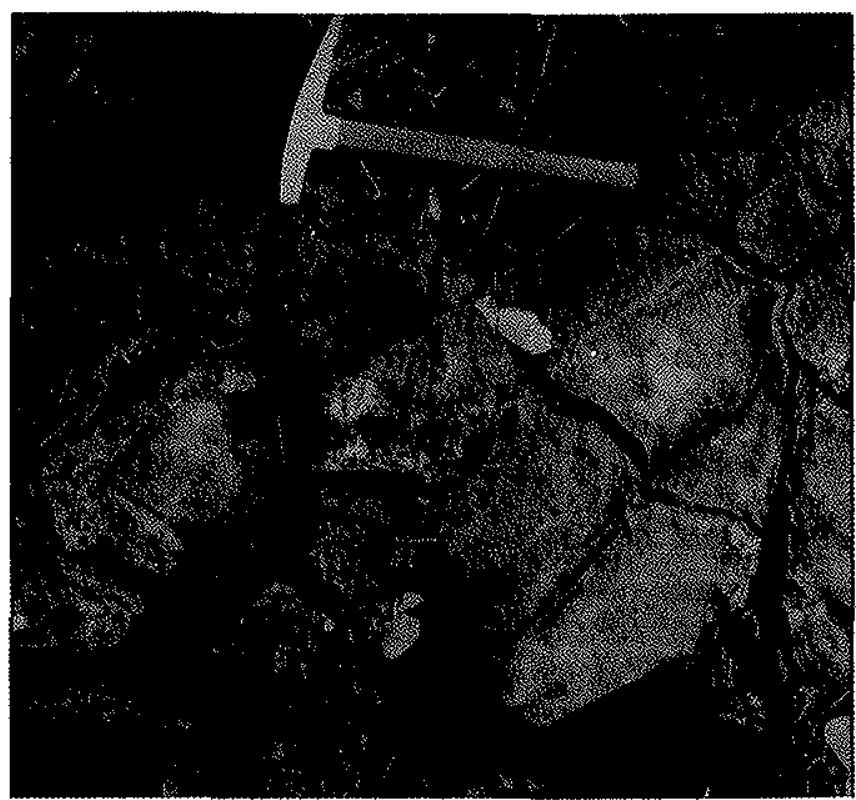

Foto 13 - Derrame ultrabásico com disjunção poliedral. Pelas dimensões dos poliedros devem corresponder as porções médias dos derrames. unidade anterior. As fraturas normalmente são ressaltadas pela erosão, podendo às vezes serem confundidas por material inter pillow.

Caracterização química preliminar Embora o número de análises químicas seja ainda muito reduzido (Tab. 1), as rochas ultrabásicas apresentam algumas relações, como $\mathrm{CaO} / \mathrm{Al}_{2} \mathrm{O}_{3}>1$, baixos valores de $\mathrm{Fe} / \mathrm{Mg}$ para dado valor de $\mathrm{Al}_{2} \mathrm{O}_{3}, \mathrm{TiO}_{2}<0,9 \%$ e $\mathrm{Na}_{2} \mathrm{O}$ e $\mathrm{K}_{2} \mathrm{O}<0,9 \%$, semelhantes aós parâmetros estabelecidos por Viljoen e Viljoen (1969), e os redefinidos por Brooks e Hart (1970) e Arndt et al., (1977) para definir rochas de filiação komatítica. Parâmetros texturais e mineralógicos (ver início deste trabalho) também sugerem esta filiação química.

A comparação com as lavas ultrabásicas do Yilgarn Block na Austrália, Munro Township no Abitibi Belt do Canadá ou Barberton na África do Sul, deverá estar fundamentada em um número bem maior de análises. De qualquer forma, as altas relações de $\mathrm{CaO} / \mathrm{Al}_{2} \mathrm{O}_{3}$ sugerem semelhanças com as lavas de Barberton.

Tabela -1

ANÁLISES QUÍMICAS \%

NORMA CIPW

\begin{tabular}{|c|c|c|c|c|c|c|c|c|c|c|c|c|}
\hline & 1 & 2 & 3 & 4 & 5 & 6 & & 1 & 2 & 3 & 4 & 5 \\
\hline $\mathrm{SiO}_{2}$ & 42.3 & 47.3 & 39.2 & 47.6 & 45.6 & 42.3 & $A p$ & - & - & - & - & - \\
\hline $\mathrm{Al}_{2} \mathrm{O}_{3}$ & 2.76 & 1.86 & 2.88 & 1.75 & 3.75 & 3.83 & II & 0.45 & 1.36 & 1.06 & 0.45 & - \\
\hline $\mathrm{Fe}_{2} \mathrm{O}_{3}$ & 2.36 & 7.38 & 1.60 & 7.97 & 0.16 & $2.23^{\prime}$ & Or & - & 0.55 & - & - & - \\
\hline $\mathrm{FeO}$ & 5.11 & 5.44 & 7.60 & 5.84 & 7.04 & 5.30 & $\mathrm{Ab}$ & 1.57 & 9.43 & 2.09 & 0.52 & 3.14 \\
\hline $\mathrm{MnO}$ & 0.26 & 0.26 & 0.19 & 0.26 & 0.19 & 0.19 & $\mathrm{Ne}$ & - & - & - & - & - \\
\hline $\mathrm{MgO}$ & 34.3 & 24.0 & 33.0 & 23.4 & 32.5 & 33,3 & An & 6.67 & 31.41 & 1.66 & 4.17 & 4.44 \\
\hline $\mathrm{CaO}$ & 2.92 & 8.65 & 3.22 & 8.39 & 3.67 & 2.80 & $\mathrm{Mgt}$ & 3.24 & 1.85 & 10.67 & 3.48 & 9.28 \\
\hline $\mathrm{Na}_{2} \mathrm{O}$ & 0.18 & 0.19 & 0.04 & 0.22 & 0.08 & 0.03 & $\mathrm{Hm}$ & - & - & - & - & - \\
\hline $\mathrm{K}_{2} \mathrm{O}$ & 0.04 & 0.04 & 0.02 & 0.03 & 0.02 & 0.03 & $\mathrm{DiCa}$ & 3.24 & 17.05 & 21.80 & - & 16.82 \\
\hline $\mathrm{TiO}_{2}$ & 0.22 & 0.53 & 0.38 & 0.54 & 0.12 & 0.12 & DiMg & 2.60 & 9.00 & 17.70 & - & 13.40 \\
\hline $\mathrm{P}_{2} \mathrm{O}_{5}$ & 0.03 & 0.04 & 0.06 & 0.03 & 0.02 & 0.02 & DiFe & 0.26 & 7.52 & 1.45 & - & 1.45 \\
\hline P.F. & 8.61 & 3.97 & 11.6 & 3.72 & 6.47 & 9.65 & HyMg & 25.30 & 9.50 & 35.80 & 29.70 & 30.30 \\
\hline TOTAL & 99.69 & 99.66 & 99.79 & 99.75 & 99.62 & 99.80 & HyFe & 2.50 & 8.05 & 3.03 & 3.69 & 3.16 \\
\hline \multirow{4}{*}{\multicolumn{7}{|c|}{$\begin{array}{l}1 \text { - Zona basal do derrame ultrabásico } \\
2 \text { - Zona de topo do derrame ultrabásico } \\
3 \text { - Zona basal do derrame ultrabásico } \\
4 \text { - Zona de spinifex do derrame ultrabásico } \\
5 \text { - Zona basal do derrame ultrabásico } \\
6 \text { - Serpentinito maciço }\end{array}$}} & Fo & 40.46 & 0.91 & - & 39.20 & 10.50 \\
\hline & & & & & & & $\mathrm{Fa}$ & 4.48 & 0.18 & - & 5.50 & 1.22 \\
\hline & & & & & & & $\mathrm{Qz}$ & - & - & 1.32 & - & - \\
\hline & & & & & & & TOTAL & 90.86 & 97.58 & 96.61 & 86.73 & 94.95 \\
\hline
\end{tabular}


DISCUSSÃo Os trabalhos envolvendo a caracterização e classificação dos corpos básico-ultrabásicos do Estado de Goiás são, de caráter específico como os apresentados por Figueiredo et al., (1975); Danni et al., (1973), Santos e Mandetta (1971) e aqueles mais abrangentes apresentando enfoque regional, como os de Angeiras (1968), Berbert (1970) e Thayer (1970).

$A$ interpretação regional dos maciços básico-ultrabásicos do Estado, obedeceu principalmente a critérios como tamanho e posicionamento estratigráfico, além de componentes litológicos. Como consequiência, individualizou-se grandes e pequenos maciços, os primeiros embutidos no embasamento siálico, enquanto os corpos serpentinizados de pequenas dimensões acham-se inseridos nos mica xistos do Grupo Araxá. Da mesma forma, os grandes maciços mostram maior diversificação litológica, possuindo termos máficos gabróicos e anortosíticos, enquanto para os pequenos corpos só se tem considerado rochas ultrabásicas (serpentinitos).

Baseado nos trabalhos específicos e regionais, poderíamos agrupar genericamente as rochas ultrabásicas em quatro grandes grupos:

1) Grandes maciços básico-ultrabásicos do tipo Niquelândia, Barro Alto e Cana Brava, mineralizados em níquel laterítico e amianto;

2) Pequenos plutons ultrabásicos serpentinizados, geralmente com zonação metamórfica de borda, como Morro Feio, Maripotaba, etc., mineralizados em amianto, talco e cromita;

3) Corpos básico-ultrabásicos diferenciados, possuindo sistema de cristalização fracionada com desenvolvimento de minerais cumulus e inter-cumulus, estando metamorfizados em condições superiores do fácies xisto verde, como Americano do Brasil, Mangabal II e I, Adelândia, Fronteira, etc., mineralizados em sulfetos de cobre e níquel;

4) Maciços ultrabásicos alcalinos com ou sem carbonato: Iporá, Catalão, Santa Fé, etc., mineralizados em níquel laterítico, fosfato, terras raras e vermiculita.

Efetivamente, a utilização de parâmetros como tamanho e tipos litológicos devem ser concebidos como uma tentativa inicial de se considerar o problema, necessitando um maior aprofundamento em dados petroquímicos e feições estruturais, que só agora começam a ser evidenciadas (Stach, 1976; Danni e Leonardos, 1978; Girardi, 1978, etc.).

Por outro lado, o cinturão serpentinítico Goiano, com suas diversas configurações $(\mathrm{X}, \mathrm{Y})$, vem sendo progressivamente mutilado, já que novos compartimentos geotectônicos têm sido estabelecidos, particularmente na porção central do Estado, com a definição das faixas de greenstone belts. Isto vem mudar substancialmente a concepção inicial do cinturão serpentinítico, que englobava praticamente todos os tipos de rochas ultrabásicas, como provenientes de uma única evoluçăo magmática eugeossinclinal.
A identificação de derrames ultrabásicos de composição komatiítica, com suas respectivas estruturas e texturas, vem diferenciar estas rochas das até então descritas na literatura geológica do Centro-Oeste brasileiro.

Como conclusão, é impossível no momento o enquadramento dos diversos corpos básico-ultrabásico de Goiás em um sistema de classificação que utilize critérios mais consistentes, como idade, ambiente geotectônico, feições estruturais, filiação magmática e depósitos minerais associados. Particularmente os corpos tipo Americano do Brasil, Mangabal e os piroxenitos - gnaisses gabróicos de Berbert (1970), não possuem no momento quaisquer condições de serem sistematizados. Achamos mais coerente, desta forma, separar apenas eventos ou épocas de magmatismo e relacionar a estes alguns tipos de corpos ultrabásicos.

- Evento arqueano, abrangendo os derrames ultrabásicos de Crixás e Goiás Velho e os complexos de Barro Alto, Niquelândia e Cana Brava.

- Evento proterozóico, representado principalmente pelos corpos serpentinizados, linearmente distribuídos ao longo do cinturão metamórfico Araxá.

- Evento mesozóico representado pelos corpos de filiação alcalina.

O primeiro evento é caracterizado, tomando por base as datações radiométricas (Schobbenhaus, $\mathrm{F}^{\circ}$ et $a l ., 1975)$ e a constatação mundialmente válida de que as lavas peridotíticas e piroxeníticas restringem-se ao Arqueano. $\mathrm{O}$ evento mesozóico, pelo número ę confiabilidade dos métodos radiométricos utilizados, não deixa margem a dúvidas. $O$ grande problema ainda se encontra com o segundo evento, onde a maioria dos corpos ultrabásicos não possui um posicionamento estratigráfico definido, nem tipo genético estabelecido. Ademais, a maioria das datações radiométricas obtidas (1000-1400 m.a.) não são conclusivas, já que podem representar o evento magmático primário ou remobilizações posteriores.

Afora o interesse científico que tal discussão desperta, deve ser ressaltado o alto significado metalogenético da sequiência ultrabásica do greenstone belt de Crixás. Além disto, a existência de lavas ultrabásicas nesta região exige uma nova estruturação geotectônica para o Maciço Central Goiano e parte do Grupo Araxá, em razão do específico condicionamento tectônico para a formação dessas rochas.

CONCLUSÓES A porção basal do greenstone belt de Crixá (área do Córrego do Alagadinho), caracteriza-se por apresentar uma sucessão de derrames ultrabásicos com texturas e estruturas primárias conservadas, além de xistos magnesianos, serpentinitos, sills gabróicos, piroxenitos e sedimentos pelíticos no topo da seqüência.

Três tipos de derrames foram reconhecidos: a) derrames ultrabásicos com textura spinifex em sua porção média, predominando a olivina; b) derrames ul- 
trabásicos com disjunção poliedral e estreita zona com textura spinifex, com predominância de clinopiroxếnio; c) derrames ultrabásicos com disjunção poliedral e eventualmente veios com textura spinifex. $O$ segundo tipo acima descrito constitui um novo modelo de derrames ultrabásicos arqueanos.

Os derrames com textura spinifex são divididos em duas unidades ( $\mathrm{A} \mathrm{e}$ B) podendo as mesmas serem subdivididas em subunidades $\mathrm{A} 1, \mathrm{~A} 2$ e $\mathrm{B} 1, \mathrm{~B} 2, \mathrm{~B} 3$ e B4. As principais estruturas dos derrames são: topo fraturado, zona de textura spinifex, olivina foliada, peridotito maciço e eventualmente peridotito nodular e disjunção poliedral.

Os derrames ultrabásicos, quando completos, apresentam feições estruturais e texturais que podem ser utilizadas como critérios estratigráficos para o estabelecimento de base e topo dos derrames e da seqüência vulcano-sedimentar.

A mineralogia primária é constituída por placas alongadas de olivina ou olivinas quench, finos esqueletos de clinopiroxênio, vidro, magnetita e/ou cromita. A paragênese metamórfica (fácie xisto verde) é formada por serpentina, clorita, tremolita-actinolita e magnetita.
As lavas ultrabásicas de Crixás apresentam composição peridotítica komatítica, caracterizada por valores de $\mathrm{MgO}>20 \%, \mathrm{CaO} / \mathrm{Al}_{2} \mathrm{O}_{3}>1, \mathrm{TiO}_{2}<0,9$, baixo teores em álcalis, que se enquadram na classificação estabelecida por Viljoen e Viljoen (1969) e Arndt et al., (1975).

As lavas peridotíticas komatíticas constituem uma nova classe de rochas ultrabásicas do Estado de Goiás. Sua origem arqueana, provavelmente acha-se relacionada com o mesmo evento tectono-magmático responsável pelos maciços de Barro Alto, Niquelândia e Cana Brava.

O reconhecimento de lavas ultrabásicas no greens. tone belt de Crixás mostra que a concepção inicial do cinturão serpentinítico Goiano, formado exclusivamente por corpos de natureza ofiolítica ou tipo alpino, deve ser revista.

Agradecimentos A Metais de Goiás S/A pelo apoio e interesse na divulgação de trabalhos que contribuam para o conhecimento geológico do Estado.

Somos também gratos a todos os colegas da METAGO pelas sugestões, particularmente Maria Celene Barbosa Ferreira, Antônio Salles, José Henrique Gomes de Castro e Eduardo Gebrim.

\section{BIBLIOGRAFIA}

ALMEIDA, F.F.M. de - 1969 - Evolução Tectônica do Centro-Oeste Brasileiro no Proterozóico Superior. An. Acad. Bras. Cien. v. 20, pp. 285-29S

ANGEIRAS, A.G. - 1968 - A faixa de serpentinitos da região central de Goiás. Inst. Geopiências. Rio de Janeiro. An. Acad. Bras. Cien. v. 40 , pp. $129-135$.

ANHAUESSER, C.R.; MASON, R.; VILJOEN, M.J. e VILJOEN, R.P. - 1969 - Reappraisal of Same Aspects of Precambrian Shield Geology. Geol. Soc. Amer. Bull, v. 80, pp. 2175-2200

ANHAEUSSER, C.R - - 1971 - The Barberton Mountain Land, South Africa: A guide to the understanding of the archean geology of Western Australia. Spec. Pbl, 3, Geol. Soc. Aust,, pp. 103-119.

ANHAEUSSER, C.R - 1973 - The evolution of the early Precambrian crust of Southern Africa. Phil. Trans., R. Soc. Lond. *A. 273, pp. 359-388.

ARNDT, N.T - 1976 - Ultramafic rocks of Munro Township: Economic and tectonic implications. Ind. Mettallogeny and Plate Tectonic D.F Strong ed. pp. 617-657

ARNDT, N.T.; NALDRETT, A.J. e PYKE, D.R. - 1977 - Komatiitic and iron rich tholeiitic lavas of Munro Township, northeast Ontario. Journal of Petrology, 18, pp. 319-369.

BARAGAR, W.R.A, e MCGLYNN, J.C. - 1976 - Early Archean basement in the Canadian - Shield: a review of the evidence. Geol. Surv. Can., Paper 76.14, 20p.

BARBOSA, O.; BAPTISTA, M.B.; DYER, R.C.; BRAUN, O.P.G. COTTA I.C. -1969 - Projeto Brasilia. Dept. ${ }^{\circ}$ Nac. Prod. Min. PROSPEC S/A, rel. inéd., Rio de Janeiro, $225 \mathrm{pp}$.

BERBERT, C.O. - 1970 - Geologia dos Complexos Básicos-Ultrabási-cos de Goiás. Anais XXIV Congr. Bras. Geol., pp. 41-50. Brasilia, Df.

BROOKS, C. e HART, S.R. - 1974 - On the significance of komatiite Geology, v. 2, pp. 107-110.

DANNI, J.C.M.; DARDENNE; M.A.; FUCK, R.A.; RIBEIRO, M.J - 1973 - Geologia da extremidade sudoeste da Serra Dourada. Rev. Bras. Geol. pp. 160-180.

DANNI, 3.C.M. e RIBEIRO, C.C. - 1978 - Caracterização da Seqüên cia Vulcano - Sedimentar de Pilar de Goiás e de Guarinos, Goiás An. XXX. Congr. Bras. Geol, pp. 582-586. Recife, PE.

DANNI J.C.M. e LEONARDOS Jr. O. - 1978 - As sequências granulítica, anortosítica-anfibolítica e ultramáfica da região de Niquelândia, Go. XXX Congr. Bras. Geol. Bol. (1), Res. das Com. pp. 45

FIGUEIREDO, A.N: MOTA, J, e MARQUES, V.J - 1975 - Estudo comparativo entre os complexos de Barro e de Tocantins, Go. Rev Bras. Geol. v. 5, pp. 15.29 .

GEBRIM, E - 1977 - Projeto Araxá. Relatório de Etapa. Metais de Goiás S/A - METAGO, Goiânia, Goiás. Inédito

GIRARDI, V.A.C. - 1978 - Estudo preliminar sobre a petrologia do maciço de Canabrava, Goiás. XXX Congr. Bras. de Geol, Bol. n. 1, Res. das Com. pp. 76.

GLIKSON, A.Y. - 1976 - Stratigraphy and evolution of primary and secondary greenstones: Significance of data from shields of the southern hemisphere in The Early History of the Earth. B. F. Windley ed. John Wilcy \& Sons, pp. 257-277.

MACGREGOR, A.N. - 1951 - Some milestones in the Precambrian of Southern Rhodesia. Trans. Geol. Soc. S. Afr., 54, pp. 27-66.

MANDETTA, P. e SANTOS, M.M. - 1977 - Classificação do complexo de Americano do Brasil. Soc. Bras. Geol. Núcleo Centro Oeste. Bol inf. $n 0^{\circ} 6$.

NILSON, A.A.; BERBERT, C.O. e MELO, J.C.R. - 1970 - Excursão n. $^{\circ} 4$; Regiōes de Morro Feio e Ipameri. XXVI Congr. Bras. Geol., Bol. Esp. n. 2, pp. 59.72. Brasilia-DF

NESBITT, R.W. - 1971 - Skeletal crystal forms in the ultramafic rock of the Yilgarn Block, Western Australia: Evidence for Archean ultramafic liquid. Geol. Soc. Australta, Spec. Publ. n. ${ }^{\circ} 3$, pp. 331-350

PENNA, G.S. - 1974 - Geologia da Área do Projeto Goiânia II, Su doeste de Goiás. An. XXVIII Congr. Bras. Geol. pp. 37-50. Porto Alegre, R.S.

PYKE, D.R $\because$ NALDRETr A J e ECKSTRAND, A.R - 1973 - Ar chean ultramafic flows in Munro Township, Ontario. Geol. Soc. Amer., Bull, 84, pp. 955-978.

SABOIA, L.A. - 1979 - Os "Greenstone Belts" de Crixás e Goiás Go: Soc. Bras. Geol. Núcleo Centro-Oeste. Bol. Inf. n. ${ }^{\circ} 9-$ pp. 43-72.

STACHE, G.D. - 1976 -. Undersuchungen Zur Geologie, Petrographie Metamorphose und Genese des Basich-Ultrabasichen MASSIUNS von Barro Alto/Goiás (Brasilien). Clausthaler Geol. Abh., v. 24, Ed Verlag, Ellen Pilger, $149 \mathrm{p}$.

THAYER T.P - 1970 - Notes on the Geology and Resources of some peridotites and relatect rocks in Brazil. U.S. Ged. Surv., Rel. inéd. BR-32 Washington, D.C., n. ${ }^{\circ} 800$.

VILJOEN, M.J. e VILJOEN, R.P. - 1969 - Evidence for the existente of mobile extrusive peridotitic magma from the Komati Formation of the Onverwacht Group. Geol. Soc. Spec. Publ. 2, Upper Mantie Project pp. 87.112

Recebido em 20 de agosto de 1979 